\title{
Experiment on Mechanical Properties of Pervious Concrete
}

\author{
K. S. B. Prasad, S. Lahari Anisha, N.V.L.N. Pavan Kumar
}

\begin{abstract}
Pervious Concrete which is also called as Noamercement Concrete is a combination of cement, water and a particular size of coarse aggregate combines to form a porous structural material. The main application of pervious concrete in pavements is for storm water control which occurs mostly in urban areas where scarcity of land is high. Permeable Pavement allows surface runoff through it and hence stops the overflow which improves ground water recharge. In this paper investigation on compressive strength, flexural strength, water permeability, density and void ratio has carried at $0.33 \%$ water cement ratio $(W / C)$ for cement aggregate ratio $(C / A) 0.25$ to three set of coarse aggregate(CA)sizes without fine aggregate. Summarizing that $12.5 \mathrm{~mm}$ (passing) to $10 \mathrm{~mm}$ (retained) size of aggregates has shown good results than remaining sizes for compressive strength, permeability, density and void content. Pervious cement concrete mix.
\end{abstract}

Index terms- Pervious Concrete, Permeable, high range water reducer, durability.

\section{INTRODUCTION}

As urbanization increases in India and also in many parts of the earthly concern there is a problem of logging of water and huge demand for drainage facility is present [1]. Pervious concrete which has feasible open spaces to provide high school permeability due to its interconnected pores allows water from precipitation and other sources to penetrate directly through and by that reduces the runoff from surface and allowing groundwater recharge. Smaller size aggregates with and without fine aggregates is used to prepare pervious concrete. Studies have been carried from past 30 years to improve ground water table and scarcity of sand.

\section{EXPERIMENTAL MATERIALS AND MIX PROPORTION}

\subsection{Cement}

In this 53 grade Deccan Cement (OPC) is used. The color of cement is gray and free from lumps. As per IS: 12269:2013. Tests are performed for cement and are according to standards.

\subsection{Mix Proportion [3]}

\begin{tabular}{|c|c|c|c|}
\hline Mix & $\begin{array}{c}\text { Cement } \\
\text { (kg/cu.mt) }\end{array}$ & $\begin{array}{c}\text { Aggregate } \\
\text { (kg/cu.mt) }\end{array}$ & $\begin{array}{c}\text { Water } \\
\text { (lit/cu.mt) }\end{array}$ \\
\hline Ratio & 1 & 4 & 0.33 \\
\hline Quantity & 450 & 1800 & 135 \\
\hline
\end{tabular}

Revised Manuscript Received on August 19, 2019.

K. S. B. Prasad, Assistant Professor, Department of Civil Engineering, GMR Institute of Technology, Rajam - 532127, Andhra Pradesh, India.

S. Lahari Anisha, U.G Student, Department of Civil Engineering, GMR Institute of Technology, Rajam - 532127, Andhra Pradesh, India. Engineering, GMR Institute of Technology, Rajam - 532127, Andhra Pradesh, India.
N.V.L.N. Pavan Kumar, P.G Student, Department of Civil

\section{Table I: Mix proportions}

\section{Preparation of Sample and Testing:}

Mechanical properties of hardened concrete are found out by performing tests of compression strength, flexural strength, porosity and permeability [1]. In order to calculate the compression strength, cylinders of dimensions $100 \times 200$ $\mathrm{mm}$ are used [10]. The proportions are then mixed and placed in the cylinder in two layers by giving 25 blows with a modified proctor hammer for each layer and is then kept for curing for about 7,14,28,56,91 days [3]. After the curing period, compression strength of the specimen is found out by testing it in the Compression Testing Machine ACTM.

\section{FLEXURAL STRENGTH TEST}

Test procedure:

The following testing procedure was undertaken during the flexural strength testing [4]:

1. The specimens for testing are prepared by molding the concrete into beams, with dimensions $500 \mathrm{~mm} \times 15 \mathrm{~mm} \times 15 \mathrm{~mm}$. support and loading has done as per IS $456-2000$

2. The specimens which are cured in water are tested immediately after taking out of water; while they are still wet. The test specimen should be placed in the machine correctly by centering with the longitudinal axis of the specimen at $90^{\circ}$ to the rollers. The loading direction should be normal to mould filling direction in case of molded specimens.

3. The load should be applied slowly without sudden loads at a rate so as to increase the stress at a rate of $0.06+0.04 \mathrm{~N} / \mathrm{mm}^{2}$ per second.

4. The Flexural Strength $\left(F_{b}\right)$ is given by,

$$
\mathbf{F}_{b}=\mathrm{P} \times \mathrm{L} /\left(\mathrm{b} \times \mathrm{d}^{2}\right)
$$

Where, $F_{b}=$ Flexural strength $\left(\mathrm{N} / \mathrm{mm}^{2}\right)$,

$\mathrm{P}=$ maximum load in $\mathrm{kg}$ applied on the specimen,

$\mathrm{L}=$ length in $\mathrm{cm}$ of the span of the support.

$\mathrm{b}=$ width of the specimen $(\mathrm{cm})$,

$\mathrm{d}=$ depth of the specimen $(\mathrm{cm})$.

\section{DENSITY AND VOID CONTENT:}

Test Procedure [9] [10]:

1. Calculate the mass of each sample core to the nearest $0.1 \mathrm{~g}$, and record it as "Initial Mass."

2. Initially dry the sample for $24 \mathrm{~h} \pm 1$ hour, and find this mass $\left(\mathrm{W}_{\mathrm{D}}\right)$, to the nearest $0.1 \mathrm{~g}$. Place the specimen in 
the oven for about one hour and note the mass again. When the difference in mass is less than $0.5 \%$, then constant mass is achieved. Drying in the oven should be continued until a constant mass is achieved.

3. In a bulk density tank-scale measuring system is filled completely with tap water, specimens are submerged completely, and place them straight for 30 minutes underwater.

4. After 30 minutes, keeping the specimen submerged in water, the side of the specimen is tapped 10 times with a rubber mallet. Rotate the specimen slightly after each tap so that they are equally spaced around the circumference of the core.

5. The mass of the specimen is measured to the nearest $0.1 \mathrm{~g}$ by submerging the specimen under water, and record it as the "Submerged Mass" $\left(\mathrm{W}_{\mathrm{S}}\right)$

Calculate the Porosity as follows:

$$
\mathbf{P}=\left[1-\left(\left(W_{D}-W_{S}\right) / \rho_{w}\right) / V_{T}\right] \times 100
$$

\section{WATER PERMEABILITY TEST:}

1. Measurement of water permeability [5][9]: As pervious concrete contains large interconnected pore network, the methods that are used to evaluate the hydraulic conductivity of normal concrete are not applicable directly. In order to estimate the hydraulic conductivity of pervious concrete, a falling head permeability cell has been designed [6].

2. The permeability cell has a $300 \mathrm{~mm}$ long acrylic tube with an inner diameter of $110 \mathrm{~mm}$. The specimen is closed in a sponge type membrane which does not absorb water. After placing the specimen in the permeability setup water will be allowed until the taken head level has filled in the graduated cylinder by closing the out let value. The head levels $22 \mathrm{~cm}$ difference has taken. Out valve should be released to check the time $(\mathrm{t})$ taken for the water filled between head levels and measured coefficient of permeability (K)

$$
\mathrm{K}=\mathrm{A}_{1} 1 / \mathrm{A}_{2} * \log \left(\mathrm{h}_{2} / \mathrm{h}_{1}\right)
$$

A1, A2 are cross-section areas of the sample and the tube. $\mathrm{L}$ is length of the specimen. $\mathrm{h}_{1}$ and $\mathrm{h}_{2}$ are initial and final heads.

Flow rate is calculated by

$\mathrm{Q}=\mathrm{KIA}$

$\mathrm{K}=$ permeability $\mathrm{m} / \mathrm{s}$

$\mathrm{I}=$ hydraluic gradient

$\mathrm{A}=$ cross sectional area $\mathrm{m}^{2}$

\section{RESULTS}

\subsection{Compressive strength:}

Table II: Compressive strength of pervious concrete 06

\begin{tabular}{|c|c|c|c|c|}
\hline $\begin{array}{c}\text { C/A } \\
\text { ratio }\end{array}$ & $\begin{array}{c}\text { W/C } \\
\text { ratio }\end{array}$ & $\begin{array}{c}\mathrm{CA} \\
(\mathrm{mm})\end{array}$ & $\begin{array}{c}\text { curing } \\
\text { period } \\
(\text { days })\end{array}$ & $\begin{array}{c}\text { compressive } \\
\text { strength } \\
\left(\mathrm{N} / \mathrm{mm}^{2}\right)\end{array}$ \\
\hline $1: 4$ & 0.33 & $6.3-4.75$ & 28 & 7.96 \\
\hline
\end{tabular}
$10 \mathrm{~mm} \mathrm{CA}$

\begin{tabular}{|c|c|c|c|c|}
\hline $\begin{array}{c}\text { C/A } \\
\text { ratio }\end{array}$ & $\begin{array}{c}\text { W/C } \\
\text { ratio }\end{array}$ & $\begin{array}{c}\mathrm{CA} \\
(\mathrm{mm})\end{array}$ & $\begin{array}{c}\text { curing } \\
\text { period } \\
\text { (days) }\end{array}$ & $\begin{array}{c}\text { compressive } \\
\text { strength } \\
\left(\mathrm{N} / \mathrm{mm}^{2}\right)\end{array}$ \\
\hline $1: 4$ & 0.33 & $12.5-10$ & 28 & 9.48 \\
\hline
\end{tabular}

Table IV: Compressive strength of pervious concrete of 11.2mm CA

\begin{tabular}{|c|c|c|c|c|}
\hline $\begin{array}{c}\mathrm{C} / \mathrm{A} \\
\text { ratio }\end{array}$ & $\begin{array}{c}\mathrm{W} / \mathrm{C} \\
\text { ratio }\end{array}$ & $\begin{array}{c}\mathrm{CA} \\
(\mathrm{mm})\end{array}$ & $\begin{array}{c}\text { curing } \\
\text { period } \\
\text { (days) }\end{array}$ & $\begin{array}{c}\text { compressive } \\
\text { strength } \\
\left(\mathrm{N} / \mathrm{mm}^{2}\right)\end{array}$ \\
\hline $1: 4$ & 0.33 & $12.5-11.2$ & 28 & 5.63 \\
\hline
\end{tabular}

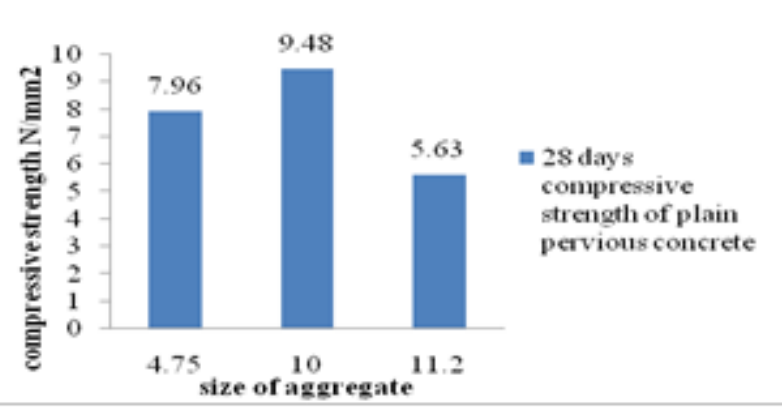

Fig 1: compressive strength of pervious Concrete of three set of aggregate sizes

6.2 Flexural strength:

Table V: shows flexural strength of $4.75 \mathrm{~mm}$ plain pervious concrete

\begin{tabular}{|c|c|c|c|c|}
\hline $\begin{array}{c}\text { Cement }- \\
\text { aggregate } \\
\text { ratio }\end{array}$ & $\begin{array}{c}\text { Water- } \\
\text { cement } \\
\text { ratio }\end{array}$ & $\begin{array}{c}\text { Size of } \\
\text { aggregate } \\
(\mathrm{mm})\end{array}$ & $\begin{array}{c}\text { Curing } \\
\text { period } \\
\text { (days) }\end{array}$ & $\begin{array}{c}\text { Flexural } \\
\text { strength } \\
\left(\mathrm{N} / \mathrm{mm}^{2}\right)\end{array}$ \\
\hline $1: 4$ & 0.33 & 4.75 & 28 & 3.03 \\
\hline
\end{tabular}

Table VI: shows flexural strength of $10 \mathrm{~mm}$ plain pervious concrete

\begin{tabular}{|c|c|c|c|c|}
\hline $\begin{array}{c}\text { Cement }- \\
\text { Aggregate } \\
\text { Ratio }\end{array}$ & $\begin{array}{c}\text { Water- } \\
\text { Cement } \\
\text { Ratio }\end{array}$ & $\begin{array}{c}\text { Size Of } \\
\text { Aggregate } \\
(\mathrm{mm})\end{array}$ & $\begin{array}{c}\text { Curing } \\
\text { Period } \\
(\text { Days })\end{array}$ & $\begin{array}{c}\text { Flexural } \\
\text { Strength } \\
\left(\mathrm{N} / \mathrm{mm}^{2}\right)\end{array}$ \\
\hline $1: 4$ & 0.33 & 10 & 28 & 2.44 \\
\hline
\end{tabular}

Table VII: shows flexural strength of $\mathbf{1 1 . 2} \mathbf{~ m m}$ plain pervious concrete

\begin{tabular}{|c|c|c|c|c|}
\hline $\begin{array}{c}\text { Cement }- \\
\text { Aggregate } \\
\text { Ratio }\end{array}$ & $\begin{array}{c}\text { Water- } \\
\text { Cement } \\
\text { Ratio }\end{array}$ & $\begin{array}{c}\text { Size Of } \\
\text { Aggregate } \\
(\mathrm{mm})\end{array}$ & $\begin{array}{c}\text { Curing } \\
\text { Period } \\
\text { (Days) }\end{array}$ & $\begin{array}{c}\text { Flexural } \\
\text { Strength } \\
\left(\mathrm{N} / \mathrm{mm}^{2}\right)\end{array}$ \\
\hline $1: 4$ & 0.33 & 11.2 & 28 & 2.33 \\
\hline
\end{tabular}




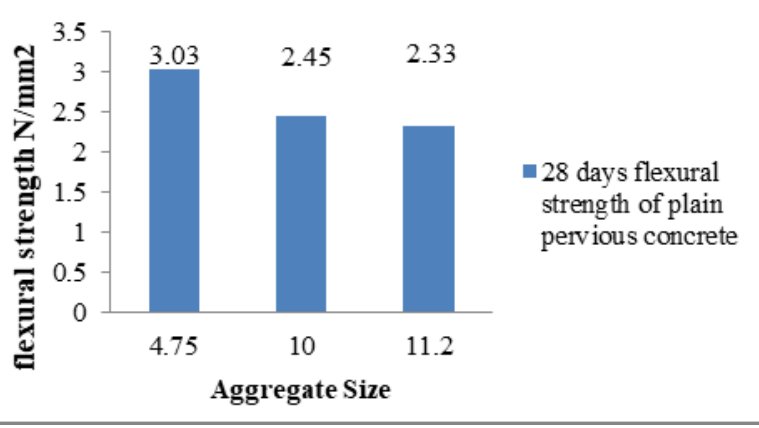

Fig 2: Flexural strength of pervious Concrete of three set of aggregate sizes

\subsection{Permeability:}

Table VIII: Permeability of plain pervious concrete

\begin{tabular}{|c|c|c|c|}
\hline $\begin{array}{c}\text { Size Of } \\
\text { Aggregate } \\
(\mathrm{mm})\end{array}$ & $\begin{array}{c}\text { Curing } \\
\text { Period } \\
(\text { Days })\end{array}$ & $\begin{array}{c}\text { Permeability } \\
(\mathrm{m} / \mathrm{s})\end{array}$ & $\begin{array}{c}\text { Flow } \\
\text { Rate }\left(\mathrm{m}^{3} / \mathrm{s}\right)\end{array}$ \\
\cline { 1 - 2 } 4.75 & \multirow{2}{*}{28} & 0.000796 & 0.00000627 \\
\cline { 1 - 1 } \cline { 4 - 4 } & & 0.00193 & 0.00001523 \\
\cline { 1 - 1 } \cline { 3 - 4 } & & 0.000842 & 0.0000066 \\
\hline 11.2 & &
\end{tabular}

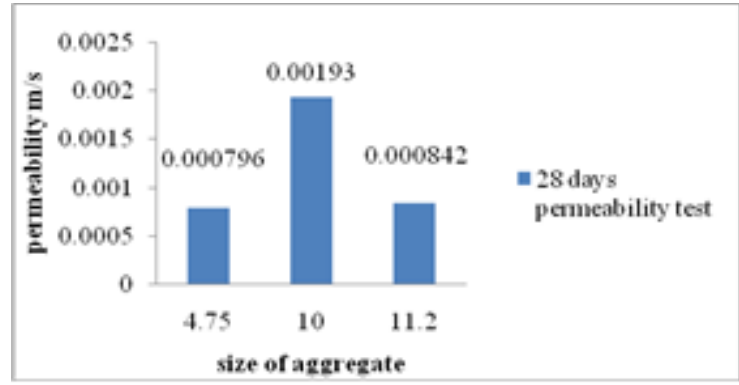

Fig 3: permeability of plain pervious concrete

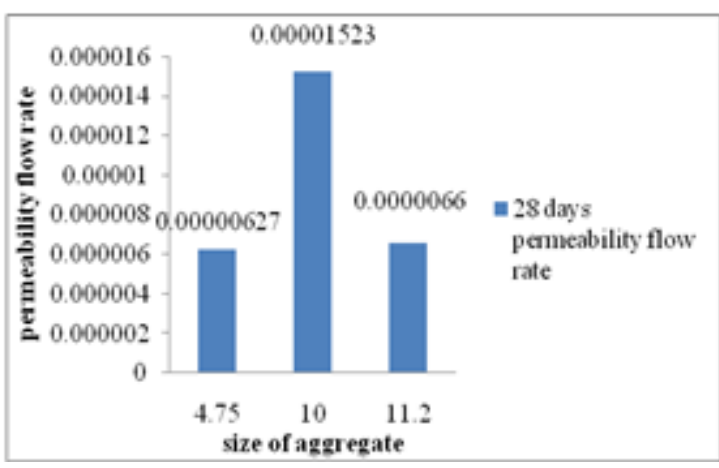

Fig 4: permeability flow rate of plain pervious Concrete

Table IX: shows 28 days' density and void ratio

\begin{tabular}{|c|c|c|l|l|c|}
\hline $\begin{array}{c}\text { Size Of } \\
\text { Aggregate } \\
(\mathrm{Mm})\end{array}$ & $\begin{array}{c}\text { Initial } \\
\text { Weight } \\
(\mathrm{Kg})\end{array}$ & $\begin{array}{c}\text { Oven } \\
\text { Dried } \\
\text { Weight } \\
(\mathrm{Kg})\end{array}$ & $\begin{array}{l}\text { Sub } \\
\text { Merged } \\
\text { Weight } \\
(\mathrm{Kg})\end{array}$ & $\begin{array}{l}\text { Density } \\
\left(\mathrm{Kg} / \mathrm{m}^{3}\right)\end{array}$ & $\begin{array}{c}\text { Void } \\
\text { Ratio } \\
(\%)\end{array}$ \\
\hline 4.75 & 3.071 & 2.963 & 1.795 & 1886.3 & 23.27 \\
\hline 10 & 3.23 & 3.118 & 1.915 & 1984.9 & 23.27 \\
\hline 11.2 & 3.155 & 3.061 & 1.8425 & 1947.2 & 22.28 \\
\hline
\end{tabular}

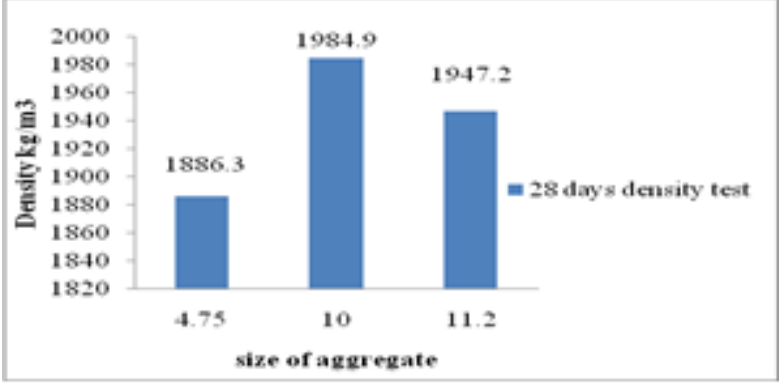

Fig 5: shows 28 days density test

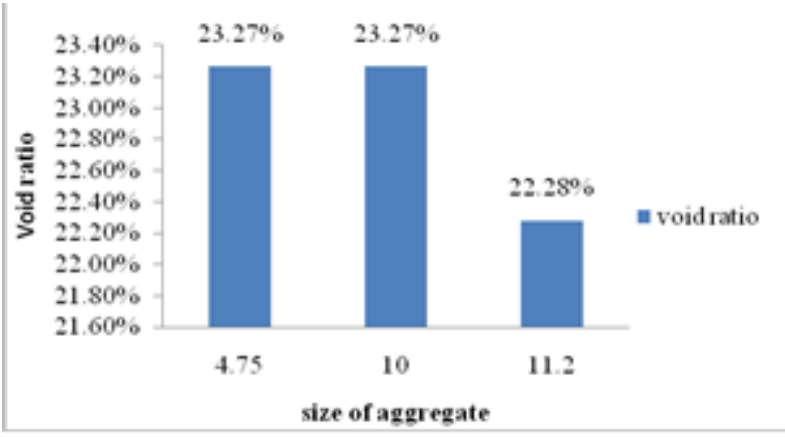

Fig 6: shows 28 days' void content

\section{CONCLUSION}

The compressive strength of plain pervious concrete for $10 \mathrm{~mm}$ size is more than $4.75 \mathrm{~mm}$ and $11.2 \mathrm{~mm}$. This shows that the compressive strength depends on size of aggregate when we observe for flexural strength in the investigation above, for $4.75 \mathrm{~mm}$ of aggregate it is higher than $10 \mathrm{~mm}$ and $11.2 \mathrm{~mm}$.

The flexural strength is increased for $4.75 \mathrm{~mm}$ due to its bonding between cement and aggregates. As it is a low grade aggregate, the binding nature will be high when compared to other. In permeability test, it is observed that the permeable nature will be high in $10 \mathrm{~mm}$ than 4.75 and $11.2 \mathrm{~mm}$ aggregates. For $10 \mathrm{~mm}$ aggregate, in the observed study the voids between the aggregates are higher than $4.75 \mathrm{~mm}$ which is bonded packly. When coming to density and void ratio, density for $10 \mathrm{~mm}$ aggregate is higher than 4.75 and $11.2 \mathrm{~mm}$ aggregates. Density for $10 \mathrm{~mm}$ aggregate is $1984.9 \mathrm{~kg} / \mathrm{m}^{3}$ which symbolizes the bonding strength between the aggregates is high when compared to other. The void ratios of $4.75 \mathrm{~mm}$ and $10 \mathrm{~mm}$ aggregates show similar values. As void ratio is high then the permeable nature will be high due to more void content. However, the compressive strength, flexural strength, permeability, density and void ratio of plain pervious concrete are satisfying the standards.

\section{REFERENCES}

1. Akshay Tejankar, Mr. Aditya Lakhe, Mr. Manish Harwani and Prem Gupta(September 2016)- "The Use of Permeable Concrete for Ground Water Recharge, International Journal of Engineering Research and Application, Vol 6, issue 9, pp 6063

2. Ammar A.Muttar, Improving the Mechanical properties of Pervious concrete, Journal of Babylon University/ Engineering Sciences / No.(2)/ Vol.(21): 2013 
3. Darshan S.Shah and Jayeskumar pitroda, (2014) An experimental study on Hardened properties of Pervious concrete, Journal of International Academic Research for Multidisciplinary Volume 2.

4. George N.McCain and Mandar M.Dewoolkar, (2009), Strength and Permeability characteristics of Porous Concrete Pavements.

5. Govind Ravish and Mr. Er .V.K.Ahuja (2015) No fines concrete as a road pavement, International Journal of Engineering Trends and Technology, Volume 24, pp 187-190

6. Schaefer, V. R., Wang, K., Suleiman, M. T., \& Kevern, J.T. (2006). Mix design development for pervious concrete in cold weather climates (No. Report No.2006- 01).0

7. B. Balaji Naik and Dr. K. Chandrasekhar Reddy, Manufacturing of Self Compaction Concrete Application of Red Mud. International Journal of Civil Engineering and Technology, 8(4), 2017, pp. 51-58.

8. P. Syam Sai and Chandana Sukesh, Strength Properties of Concrete By Using Red Mud as a Replacement of Cement with Hydrated Lime. International Journal of Civil Engineering and Technology, 8(3), 2017, pp. 38-49.

9. Tejas Joshi and Dr. Urmil Dave evaluation of strength, permeability and void ratio of pervious concrete with changing $\mathrm{w} / \mathrm{c}$ ratio and aggregate sizeInternational Journal of Civil Engineering and Technology (IJCIET) Volume 7, Issue 4, July-August 2016, pp. 276-284

10. Nzmrca technical note 9 pervious concrete(2016). 